\title{
STRUKTURA FINANSOWANIA INWESTYCJI MALYCH I ŚREDNICH PRZEDSIĘBIORSTW REFUNDOWANYCH Z FUNDUSZY EUROPEJSKICH W WIELKOPOLSCE
}

\begin{abstract}
Fundusze Unii Europejskiej mają korzystny wpływ na dynamikę produktu krajowego brutto. Zwiększają konkurencyjność i innowacyjność polskiej gospodarki, wspomagają także rozwój przedsiębiorstw, szczególnie podmiotów należących do sektora małych i średnich przedsiębiorstw. Te ostatnie nie mają bowiem wystarczającej ilości kapitałów własnych, a obce źródła finansowania są dla nich najczęściej bardzo trudno dostępne, między innymi ze względu na brak zdolności kredytowej oraz wystarczających zabezpieczeń. Przedsiębiorcy prowadzący działalność gospodarczą w Polsce od 1 maja 2004 roku mogą ubiegać się o wsparcie finansowe pochodzące $\mathrm{z}$ wielu źródeł wspólnotowych. Fundusze Unii Europejskiej w postaci bezzwrotnych dotacji są bowiem dostępne dla polskich przedsiębiorstw głównie w formie programów wspólnotowych oraz funduszy strukturalnych. Największym zainteresowaniem cieszyły się programy, z których polskie firmy mogły uzyskać dotacje na inwestycje w formie bezpośredniego wsparcia na zasadzie refundowania kosztów inwestycji czy preferencyjnych pożyczek. W niniejszym artykule zbadano strukturę finansowania przedsięwzięć inwestycyjnych dokonywanych przez małe i średnie przedsiębiorstwa, które uzyskały dotację z funduszy europejskich. Podjęto próbę zidentyfikowania przedmiotu oraz celów inwestycyjnych niewielkich firm na tle wykorzystywanych przez nie różnych form zasilania kapitałowego. Zbadano również zakres realizowania inwestycji przez małe i średnie podmioty w obliczu nieotrzymania refundacji z funduszy strukturalnych wskazując jednocześnie na źródła finansowania przedsięwzięć inwestycyjnych w obliczu braku pomocy publicznej. Przedstawione w niniejszym artykule wyniki badań dotyczą rezultatów bezpośredniej pomocy dla MŚP w formie refundacji z funduszy strukturalnych, pozyskanych w programowaniu 2004-2006 i rozliczonych w kolejnych dwóch latach. Analizę empiryczną oparto na wynikach badania ankietowego, obejmującego 110 firm należących do sektora MŚP funkcjonujących w województwie wielkopolskim, które otrzymały dofinansowanie z Sektorowego Programu Operacyjnego Wzrost Konkurencyjności Przedsiębiorstw. Badanie przeprowadzono wśród 52 podmiotów małych i 58 średnich.

Słowa kluczowe: firma, inwestycja, kredyt, fundusze strukturalne, konkurencyjność,
\end{abstract} innowacyjność.

\section{WSTĘP}

Fundusze europejskie mają niewątpliwie korzystny wpływ na dynamikę produktu krajowego brutto, zwiększają konkurencyjność i innowacyjność polskiej gospodarki, wspomagają także rozwój przedsiębiorstw, szczególnie podmiotów należących do sektora

\footnotetext{
1 Dr Paweł Mikołajczak, Wydział Ekonomii, Uniwersytet Ekonomiczny w Poznaniu, Al.
} Niepodległości 10, 61-875 Poznań, e-mail:pawel.mikolajczak@ue.poznan.pl. 
małych i średnich przedsiębiorstw. Te ostatnie nie mają bowiem wystarczającej ilości kapitałów własnych, a obce źródła finansowania są dla nich najczęściej bardzo trudno dostępne ze względu na brak zdolności kredytowej. Zjawisko to nazywane jest luka kapitałową ${ }^{2}$. Szansą na poprawę sytuacji niewielkich podmiotów ekonomicznych stały się właśnie fundusze strukturalne, które wprawdzie nie mogą stanowić jedynego czynnika poprawy ich sytuacji ekonomicznej, jednak ich absorpcja może się okazać ważnym czynnikiem poprawy ich dostępności do zewnętrznych źródeł finansowania inwestycji ${ }^{3}$. Małe i średnie przedsiębiorstwa mają możliwość korzystania z szerokiego spektrum funduszy unijnych przeznaczonych do realizacji ich działań inwestycyjnych już od 2000 roku. Najpierw były to fundusze przedakcesyjne, potem fundusze strukturalne na lata 2004-2006, a obecnie środki dostępne w programowaniu 2007-2013 ${ }^{4}$.

Ostateczne efekty współfinansowanych ze środków europejskich inwestycji dokonywanych przez polskie firmy w danym programowaniu można zidentyfikować dopiero po kilku latach, ponieważ proces inwestycyjny ma charakter długoterminowy. Przedstawione w niniejszym artykule wyniki badań dotyczą rezultatów bezpośredniej pomocy dla MŚP w formie refundacji z funduszy strukturalnych, pozyskanych w programowaniu 2004-2006 i rozliczonych w kolejnych dwóch latach. Zaprezentowano je na tle wykorzystywanych zewnętrznych źródeł finansowania dotowanych inwestycji.

Analizę empiryczną oparto na wynikach badania ankietowego, obejmującego 110 firm należących do sektora MŚP funkcjonujących w województwie wielkopolskim. Materiał empiryczny powinien obejmować 242 przedsiębiorstwa, a więc wszystkie podmioty funkcjonujące na terenie województwa wielkopolskiego, które otrzymały dofinansowanie z Sektorowego Programu Operacyjnego Wzrost Konkurencyjności Przedsiębiorstw dotyczącego bezpośredniego wsparcia MŚP. Uzyskano 174 ankiety, w tym 146 ankiet kompletnych, które można było wykorzystać do dalszej obróbki statystycznej. W toku weryfikacji zebranego materiału badawczego odrzucono 36 ankiet ze względu na poważne błędy logiczne, które dyskwalifikowały je pod względem merytorycznym. Badanie przeprowadzono wśród 52 podmiotów małych i 58 średnich.

\section{POMOC UNII EUROPEJSKIEJ W FINANSOWANIU INWESTYCJI MALYCH I ŚREDNICH PRZEDSIĘBIORSTW W POLSCE}

Przystąpienie Polski do Unii Europejskiej wiąże się z dostępem różnego rodzaju podmiotów ekonomicznych do funduszy strukturalnych i kilkudziesięciu programów wspólnotowych przeznaczonych na działania inwestycyjne w różnych sektorach gospodarki, między innymi w zakresie podnoszenia konkurencyjności przedsiębiorstw,

\footnotetext{
${ }^{2} \mathrm{~K}$. Górka, Zjawisko luki kapitałowej $w$ finansowaniu mikro-, małych $i$ średnich przedsiębiorstw $w$ Polsce w latach 2007-2011, „Ekonomia, Economics” 4 (21), Wydawnictwo Uniwersytetu we Wrocławiu, Wrocław 2012, s. 212-213.

${ }^{3}$ P. Mikołajczak, Źródła finansowania inwestycji małych i średnich przedsiębiorstw refundowanych ze środków strukturalnych Unii Europejskie, [w:] Ryzyko w działalności gospodarczej. Finansowanie matych $i$ średnich przedsiębiorstw $w$ okresie zagrożenia ryzykiem, red. A. Janc, K. Waliszewski, Wydawnictwo UEP, Poznań 2012, s. 184.

${ }^{4}$ M. Proczek, Wsparcie finansowe dla sektora MSP $w$ Polsce $z$ funduszy strukturalnych $w$ latach 2004-2006, [w:] Finansowanie MSP w Polsce ze środków finansowych UE jako czynnik wpływający na konkurencyjność przedsiębiorstw, red. E. Latoszek, Wydawnictwo SGH, Warszawa 2008, s. $170-175$.
} 
poszukiwania i wdrażania nowych rozwiązań technologicznych, współpracy z jednostkami badawczo-rozwojowymi, infrastruktury transportowej, inwestycji na rzecz ochrony środowiska oraz szkoleń zawodowych dla pracowników i kadry zarządzającej ${ }^{5}$.

Przedsiębiorcy prowadzący działalność gospodarczą w Polsce od 1 maja 2004 r. mogą ubiegać się o wsparcie finansowe pochodzące $\mathrm{z}$ wielu źródeł wspólnotowych. Fundusze Unii Europejskiej w postaci bezzwrotnych dotacji są bowiem dostępne dla polskich przedsiębiorstw głównie w formie programów wspólnotowych oraz funduszy strukturalnych.

Europejski Fundusz Rozwoju Regionalnego (EFRR) to największy wspólnotowy instrument finansowania dla małych i średnich przedsiębiorstw, którego celem jest zmniejszenie różnic w rozwoju regionów i umocnienie społecznej i gospodarczej spójności Unii Europejskiej. W ramach EFRR współfinansuje się działania nakierowane na zwiększenie liczby powstających MŚP, wzmocnienie ich konkurencyjności i innowacyjności. Dotyczą one następujących dziedzin:

- inicjatywy na rzecz rozwoju przedsiębiorczości, innowacyjności i konkurencyjności MŚP, zwłaszcza w dziedzinie stosowania innowacyjnych technologii, systemów zarządzania, wykorzystywania nowoczesnych technologii informatycznych, innowacji ekologicznych w MŚP;

- poprawy otoczenia dla małych i średnich przedsiębiorstw na poziomie regionalnym i lokalnym między innymi poprzez większy dostęp do kapitału dla MŚP w fazie powstawania i wzrostu, rozwój infrastruktury gospodarczej i poszerzenie zakresu usług wspierających niewielkie przedsiębiorstwa, zwiększenie potencjału w zakresie innowacji, badań i rozwoju technologicznego czy możliwości w dziedzinie współpracy gospodarczej i innowacji;

- $\quad$ inicjatywy na rzecz poszerzenia współpracy trans granicznej i międzynarodowej MŚP

- $\quad$ ochrony i poprawy stanu środowiska;

- $\quad$ rozwoju turystyki i oraz inwestycji w dziedzinie kultury;

- $\quad$ inwestowania w zasoby ludzkie 6

W programowaniu 2004-2006 największym zainteresowaniem cieszyły się programy, $\mathrm{z}$ których polskie firmy mogły uzyskać dotacje na inwestycje $\mathrm{w}$ formie bezpośredniego wsparcia na zasadzie refundowania kosztów inwestycji czy preferencyjnych pożyczek. W latach 2006-2008 był to głównie Sektorowy Program Operacyjny - Wzrost Konkurencyjności Przedsiębiorstw. Ogromne zainteresowanie tym programem skutkowało koniecznością kilkukrotnego przesunięcia pieniędzy z innych źródeł.

Dokonując natomiast przeglądu list przedsiębiorstw aplikujących o dotację na inwestycje i rekomendowanych do udzielenia wsparcia z liczbą podmiotów, które uzyskały pozytywną ocenę merytoryczną, jednak ze względu na niewystarczającą wielkość budżetu nie mogły zostać objęte refundacją, można wywnioskować, że popyt na tę formę finansowego zasilania polskich MŚP istnieje również w programowaniu 2007-

\footnotetext{
5 Ernst \& Young, Pomoc Unii Europejskiej dla przedsiębiorców, C.H. BECK, Warszawa 2004, s. 1-5.

6 Ministerstwo Infrastruktury i Rozwoju, http://www.funduszeeuropejskie.gov.pl (dostęp: 28 grudnia 2013).
} 
2013. Dotyczy to zasadniczo Regionalnych Programów Operacyjnych, a także funduszy o zasięgu krajowym.

Istotną kwestią związaną $\mathrm{z}$ realizacją inwestycji objętych wsparciem $\mathrm{z}$ funduszy strukturalnych jest fakt, że konstrukcja korzystania ze środków unijnych wymaga sfinansowania w całości kosztów inwestycji przez potencjalnego beneficjenta, które po jej rozliczeniu są w części zwracane firmie lub instytucji ją finansującej. Mimo że możliwości korzystania z zewnętrznych źródeł finansowania inwestycji przez sektor MŚP są nadal ograniczone najczęściej $\mathrm{z}$ powodu braku wystarczająco długiej historii finansowej oraz zabezpieczeń, to fundusze europejskie stanowią ważny czynnik poprawy ich dostępności do różnych form finansowania obcego. Te ostatnie mają bowiem charakter pomostowy. Znaczna jego część zwracana jest w momencie uzyskania refundacji ${ }^{7}$.

\section{RODZAJE I ZAKRES INWESTYCJI REFUNDOWANYCH Z FUNDUSZY UNII EUROPEJSKIEJA ŹRÓDŁA ICH FINANSOWANIA}

W pierwszej kolejności dokonano analizy źródeł finansowania inwestycji współfinansowanych $\mathrm{z}$ funduszy europejskich przez małe i średnie przedsiębiorstwa, uwzględniając przedmiot finansowanego przez nie przedsięwzięcia inwestycyjnego. Badania wskazują, że małe jednostki głównie finansowały inwestycje ze środków własnych. Najczęściej finansowały z nich zakup sprzętu komputerowego $(60,6 \%)$, a w dalszej kolejności wartości niematerialne i prawne oraz maszyny (kolejno: 48,8\% i $46,1 \%$ ). Tylko $25 \% \mathrm{z}$ nich sięgało po własne zasoby w celu finansowania budynków. Te ostatnie natomiast aż w 72,7\% finansowane były kredytem bankowym.

Interesujące poznawczo wydają się rezultaty niniejszego badania wśród średnich podmiotów. Finansowały one inwestycje najczęściej poprzez kredyt, przy czym wartości niematerialne i prawne stanowiły największy odsetek - aż 69\% z nich. Nieco mniej średnich firm finansowało $\mathrm{z}$ kredytu bankowego budynki oraz maszyny (kolejno: 56,1\% oraz 51,2\%). Wśród podmiotów średniej wielkości około $48 \%$ jednostek finansowało inwestycje w komputery ze środków własnych oraz budynki (43,9\% z nich). Warto również zwrócić uwagę na leasing jako formę finansowania inwestycji współfinansowanych ze środków UE. Na podstawie przeprowadzonej analizy można zauważyć, że z tej formy zasilania kapitałowego korzystały głównie małe podmioty przy zakupie maszyn $(23,5 \%)$ oraz komputerów (10,4\%). Wyniki zaprezentowanej analizy wskazują, że bez względu na przedmiot inwestycji częściej wybieranym źródłem finansowania małych jednostek są środki własne. Średnie podmioty natomiast chętniej sięgają po zewnętrzne kapitały głównie finansujące ich inwestycje w wartości niematerialne i prawne. Świadczyć to może nie tylko o silniejszej niż mniejszych jednostek sytuacji finansowej podmiotów o średniej skali wytwarzania, ale również o większej orientacji na inwestycje budujące trwalszą przewagę konkurencyjną, czyli wartości niematerialne i prawne (rys. 1).

\footnotetext{
${ }^{7}$ W. Czternasty, P. Mikołajczak, Rozwój matych i średnich przedsiębiorstw w Polsce a źródła ich finansowania. Wspótczesne dylematy, [w:] Nowe trendy w metodologii nauk ekonomicznych, t. I: Problemy ogólne metodologii nauk ekonomicznych, red. A. Grzelak, K. Pająk, Wydawnictwo UEP, Poznań 2010, s. 45-46.
} 
$\mathrm{Z}$ inwestycyjnego punktu widzenia istotne wydają się również cele przyświecające przedsiębiorstwom dokonującym inwestycji współfinansowanych ze środków Unii Europejskiej. Przeprowadzono ankietę, gdzie podmioty małej i średniej wielkości miały wskazać cel, który zamierzały osiągnąć dzięki przedsięwzięciom inwestycyjnym, refundowanym $\mathrm{z}$ funduszy UE oznaczonych w kolejności symbolami od C1 do C6 i opisanych następująco:

- $\quad \mathrm{C} 1$ - zwiększenie konkurencyjności na rynku krajowym;

- $\quad \mathrm{C} 2$ - zwiększenie konkurencyjności na rynku międzynarodowym;

- $\quad$ C3 - poprawa jakości oferowanych dóbr/usług;

- $\quad \mathrm{C} 4$ - zwiększenie bazy kapitałowej;

- $\quad$ C5 - rozwój strategii eksportowej.

Rys. 1. Rodzaje współfinansowanych z funduszy strukturalnych inwestycji małych i średnich firm w latach 2004-2008 a źródła ich finansowania

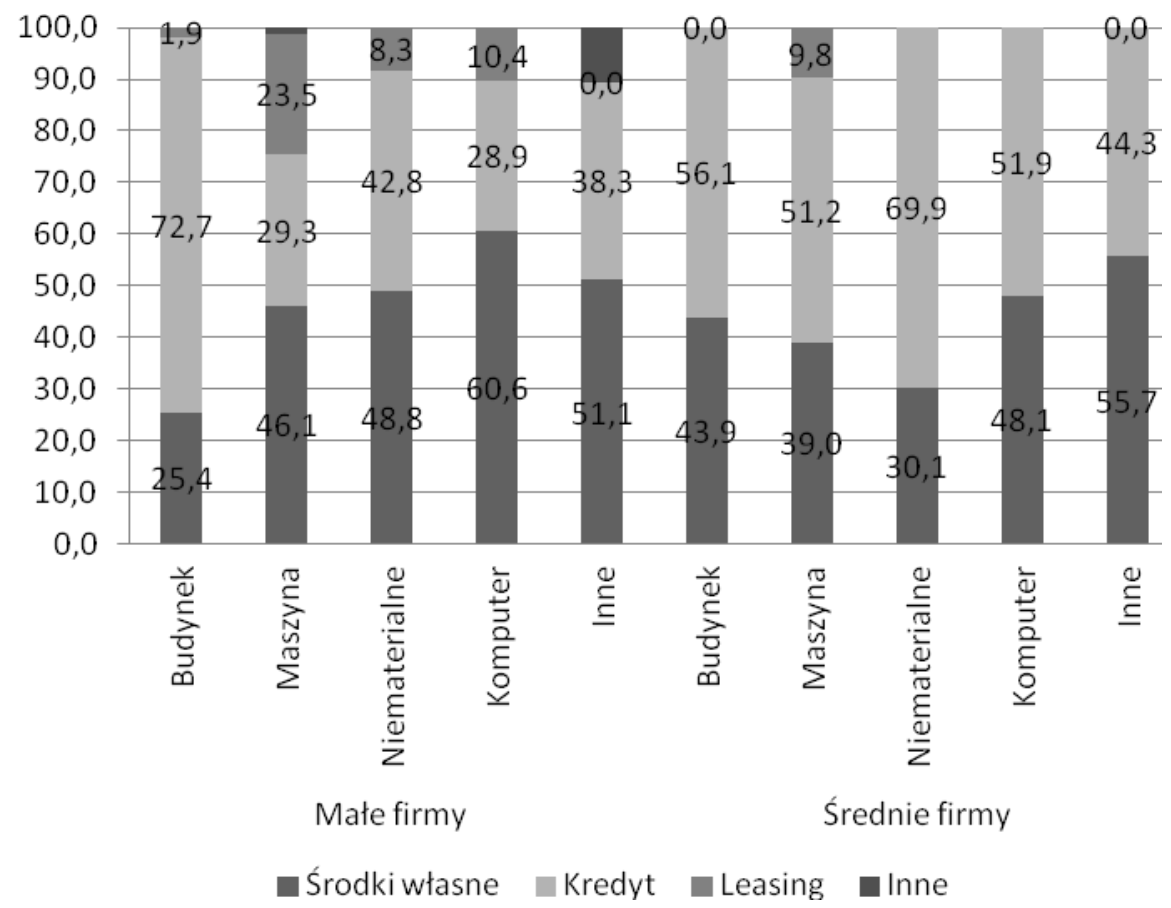

Źródło: opracowanie własne na podstawie informacji zawartych w kwestionariuszach ankietowych Wplyw funduszy strukturalnych na rozwój matych $i$ średnich przedsiębiorstw $w$ województwie wielkopolskim

Tak sformułowane priorytety inwestycyjne skonfrontowano ze źródłami finansowania nabywanych składników majątku w podziale na małe i średnie przedsiębiorstwa. Spośród wskazanych celów inwestycyjnych ze środków własnych najczęściej finansowano w przypadku firm małych $\mathrm{C} 1$, a więc zwiększenie konkurencyjności na rynku krajowym, oraz C3, czyli poprawę jakości oferowanych dóbr/usług (kolejno 47\% i 45,4\%). Nieco 
mniej firm wskazywało na zwiększenie konkurencyjności na rynku międzynarodowym jako priorytet inwestycyjny finansowany $\mathrm{z}$ własnych zasobów pieniężnych. Najmniejszy odsetek małych przedsiębiorstw finansowało ze środków własnych inwestycje, których celem było zwiększenie bazy kapitałowej. Co ciekawe, aż 75\% najmniejszych podmiotów finansowało kredytem inwestycje, których celem było zwiększenie bazy kapitałowej. Pozostałe priorytety inwestycyjne były zasilane kredytem bankowym przez około $30 \%$ małych podmiotów. Leasing natomiast stanowił tę formę finansowania inwestycji wspieranych przez środki europejskie, których celem było głównie rozwijanie strategii eksportowej (32,8\% małych firm), a w dalszej kolejności poprawa jakości oferowanych produktów/usług $(25,9 \%)$ oraz wzrost konkurencyjności na rynku międzynarodowym i krajowym (kolejno $23,1 \%$ oraz 21,6\%). Inaczej kształtowały się wyniki badań dla przedsiębiorstw średnich. Zwiększenie bazy kapitałowej, w odróżnieniu do małych podmiotów, było tym celem, na który średniej wielkości firmy wskazały najczęściej jako cel finansowany ze środków własnych (aż 66\%). Te ostatnie zasilały także inwestycje, których celem było zwiększenie konkurencyjności na rynkach zagranicznych - niecałe $40 \%$ firm średnich, oraz poprawa konkurencyjności krajowej i rozwój strategii eksportowej - około 37\%. Kredyt bankowy cieszył się największym zainteresowaniem wśród firm o średniej skali wytwarzania realizujących inwestycje zorientowane na osiągnięcie wszystkich zaprezentowanych celów. Dotyczyło to połowy ankietowanych średnich przedsiębiorstw. Najmniejszy odsetek tych podmiotów finansował kredytem inwestycje współfinansowane $\mathrm{z}$ funduszy UE, których celem było zwiększenie bazy kapitałowej $(33,9 \%)$. Leasing z kolei głównie służył poprawie jakości oferowanych przez średnie jednostki dóbr i usług (rys. 2).

Rys. 2. Cele współfinansowanych z funduszy strukturalnych inwestycji małych i średnich firm w latach 2004-2008 a źródła ich finansowania

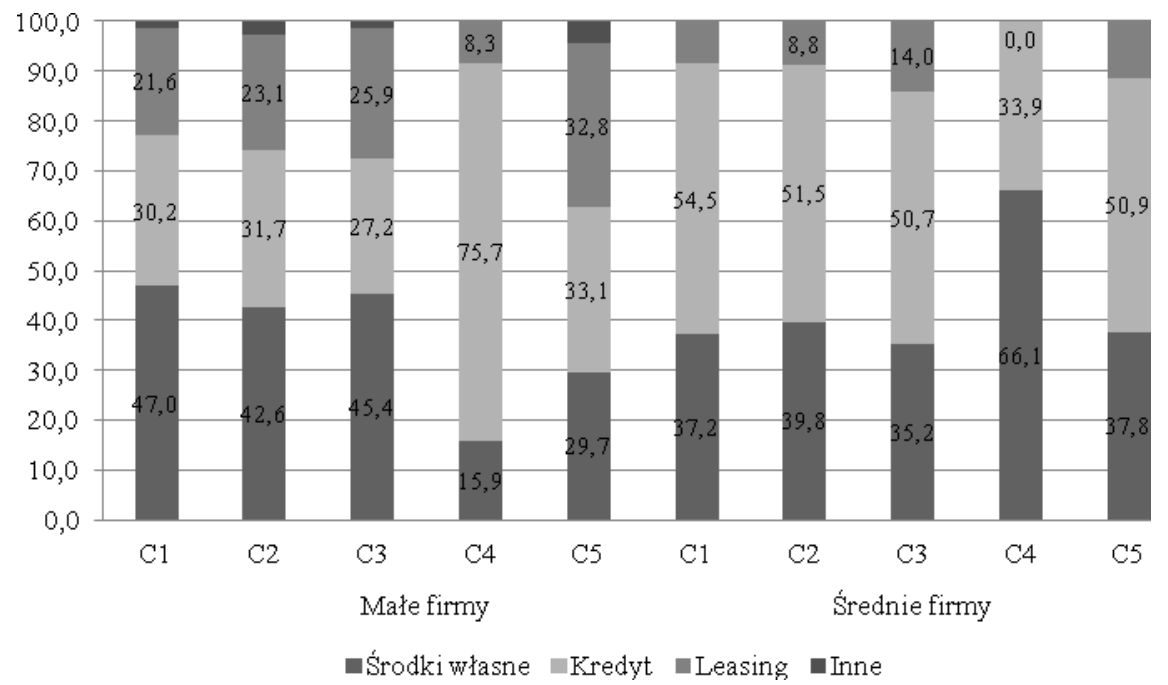

Źródło: opracowanie własne na podstawie informacji zawartych w kwestionariuszach ankietowych Wpływ funduszy strukturalnych na rozwój małych i średnich przedsiębiorstw $w$ województwie wielkopolskim 


\section{ZAKRES REALIZACJI INWESTYCJI MALYCH I ŚREDNICH FIRM W OBLICZU NIEOTRZYMANIA REFUNDACJI Z FUNDUSZY STRUKTURALNYCH W LATACH 2004-2008 A ŹRÓDLA ICH FINANSOWANIA}

Decyzje inwestycyjne każdego przedsiębiorstwa powinny być podejmowane na podstawie rachunku ekonomicznego rozumianego jako ocena opłacalności projektów inwestycyjnych. Takie podejście uprawdopodabnia finansowy sukces przedsięwzięcia inwestycyjnego. Fundusze europejskie stanowią czynnik, który niewątpliwie powinien zwiększać skłonność przedsiębiorstw do dokonywania inwestycji, gdyż z jednej strony unijna pomoc bezpośrednia skraca okres jej zwrotu, z drugiej zaś stanowi swoistego rodzaju weryfikację jej zasadności ze względu na konieczność spełnienia postawionych celów każdego projektu 8 .

W kolejnym etapie badań zatem postawiono beneficjentom funduszy europejskich pytania, których celem było zweryfikowanie zamierzeń inwestorów w sytuacji, gdyby dotacja nie została przyznana (tab. 1). Następnie zbadano, z jakich źródeł finansowania korzystały małe i średnie firmy w sytuacji nieotrzymania dotacji (tab. 2). Możliwe były następujące warianty odpowiedzi, oznaczone kolejno od Z1 do Z5:

- $\mathrm{Z} 1$ - zostałby on zrealizowany w terminie i zakresie przewidzianym we wniosku;

- Z2 - zostałby on zrealizowany w terminie późniejszym, w zakresie przewidzianym we wniosku;

- Z3 - zostałby on zrealizowany $\mathrm{w}$ terminie przewidzianym we wniosku, ale $\mathrm{w}$ ograniczonym zakresie;

- Z4 - zostałby on zrealizowany $\mathrm{w}$ terminie późniejszym i w ograniczonym zakresie;

- Z5 - nie zostałby on zrealizowany w ogóle.

Okazało się, że $47,2 \%$ firm zrealizowałoby inwestycję w pełnym zakresie, choć połowa z nich odłożyłaby ją na późniejszy termin. Wśród pozostałych firm $30,9 \%$ wykonałoby go w późniejszym terminie i ograniczonym zakresie. $Z$ kolei co dziesiąte przedsiębiorstwo w razie niezakwalifikowania projektu do realizacji nie przeprowadziłoby go w ogóle. Można zatem wnioskować, że nieotrzymanie dofinansowania z funduszy strukturalnych uniemożliwiało niewielkim firmom zrealizowanie planowanych inwestycji w takim zakresie rzeczowym i czasowym, jaki by chciały bez względu na ich wielkość. Większość z nich odłożyłaby inwestycje na późniejszy termin i ograniczyłaby zakres przedsięwzięć inwestycyjnych. Świadczy to o dużej roli, jaką pomoc finansowa UE odgrywa w procesie podejmowania działań inwestycyjnych w sektorze MŚP.

Wśród małych podmiotów prawie połowa ankietowanych firm, która przy braku dotacji realizowałaby inwestycje $\mathrm{w}$ terminie i zakresie przewidzianym we wniosku lub w późniejszym czasie, ale $\mathrm{w}$ zakresie przewidzianym we wniosku sfinansowała refundowaną inwestycję ze środków własnych. Firmy, które deklarowały realizację projektu $\mathrm{w}$ terminie późniejszym i w ograniczonym zakresie lub rezygnujących $\mathrm{z}$ inwestycji przy braku dotacji w nieco mniejszym stopniu sięgały po własne zasoby, realizując współfinansowaną ze środków UE inwestycję (kolejno: 47,4\% oraz 48,1\%).

\footnotetext{
${ }^{8}$ P. Mielcarz, P. Paszczyk, Analiza projektów inwestycyjnych $w$ procesie tworzenia wartości przedsiębiorstwa, Wydawnictwo Naukowe PWN, Warszawa 2013, s. 20-21.
} 
Tabela 1. Wielkość firmy a stopień realizacji inwestycji w sytuacji nieotrzymania refundacji z funduszy strukturalnych w latach 2004-2008

\begin{tabular}{|c|c|c|c|c|c|c|}
\hline \multirow[b]{2}{*}{$\begin{array}{c}\text { Wielko } \\
\text { ść } \\
\text { firmy }\end{array}$} & \multirow[b]{2}{*}{ Ogółem } & \multicolumn{5}{|c|}{ Stopień realizacji inwestycji przy braku dotacji } \\
\hline & & \begin{tabular}{|c} 
W \\
przewidzian \\
ym \\
terminie
\end{tabular} & $\begin{array}{c}\text { W } \\
\text { późniejszy } \\
\text { m terminie }\end{array}$ & $\begin{array}{c}\text { W } \\
\text { przewidzianym } \\
\text { terminie } \\
\text { i ograniczonym } \\
\text { zakresie }\end{array}$ & \begin{tabular}{|c|}
$W$ \\
późniejszym \\
terminie i \\
ograniczonym \\
zakresie
\end{tabular} & $\begin{array}{c}\text { Brak } \\
\text { realizac } \\
\text { ji }\end{array}$ \\
\hline & \multicolumn{6}{|c|}{ w liczbach absolutnych } \\
\hline Ogółem & 110 & 26 & 26 & 12 & 34 & 12 \\
\hline Mała & 52 & 12 & 10 & 6 & 17 & 7 \\
\hline \multirow[t]{2}{*}{ Średnia } & 58 & 14 & 16 & 6 & 17 & 5 \\
\hline & \multicolumn{6}{|c|}{ w procentach w $i$-tym wierszu } \\
\hline Ogółem & 100,0 & 23,6 & 23,6 & $\mathbf{1 0 , 9}$ & 30,9 & 10,9 \\
\hline Małe & 100,0 & 23,1 & 19,2 & 11,5 & 32,7 & 13,5 \\
\hline Średnie & 100,0 & 24,1 & 27,6 & 10,3 & 29,3 & 8,6 \\
\hline
\end{tabular}

Źródło: opracowanie własne na podstawie informacji zawartych $\mathrm{w}$ kwestionariuszach ankietowych Wplyw funduszy strukturalnych na rozwój malych i średnich przedsiębiorstw $w$ województwie wielkopolskim

Wśród przedsiębiorstw, które korzystały ze środków własnych, 38,9\% wykonałoby projekt $\mathrm{w}$ terminie przewidzianym we wniosku, ale $\mathrm{w}$ ograniczonym zakresie, gdyby nie dostały dotacji. Aż $61,1 \%$ respondentów, którzy w razie nieotrzymania dotacji realizowałaby projekt $\mathrm{w}$ terminie przewidzianym we wniosku, ale $\mathrm{w}$ ograniczonym zakresie, pozyskała kredyt bankowy na inwestycje współfinansowane z Unii Europejskiej. W dalszej kolejności podmioty, które wykonywałyby inwestycje w terminie późniejszym, choć $\mathrm{w}$ zakresie przewidzianym $\mathrm{w}$ projekcie przy odmowie refundacji $(36,9 \% \mathrm{z}$ nich), finansowały projekt, posiłkując się kredytem. Wśród małych jednostek, które zdecydowałyby się na realizację inwestycji $\mathrm{w}$ terminie i zakresie przewidzianym we wniosku, 11,3\% w sytuacji braku dofinansowania ze funduszy Unii Europejskiej sięgały po zewnętrzne źródła finansowania dotowanej inwestycji w postaci kredytu bankowego. Inaczej kształtował się odsetek podmiotów korzystających z leasingu. Właśnie po tę formę finansowania inwestycji w 39,3\% sięgnęły małe przedsiębiorstwa, które zdecydowałyby się ją realizować bez refundacji w terminie i zakresie przewidzianym $\mathrm{w}$ dokumentacji aplikacyjnej. Aż 84,7\% przedsiębiorstw o średniej skali wytwarzania rezygnujących $\mathrm{z}$ realizacji projektu przy braku dofinansowania lokowały własne środki w inwestycje współfinansowane $\mathrm{z}$ funduszy Unii Europejskiej. Te ostatnie stanowiły również źródło finansowania dotowanej inwestycji dla 38,2\% średnich firm deklarujących realizację projektu w terminie późniejszym i w ograniczonym zakresie. Znaczny odsetek podmiotów $(60,4 \%)$, które przy odmowie dotacji wykonałyby inwestycje w terminie $\mathrm{i}$ zakresie przewidzianym we wniosku, sięgnał po kredyt bankowy, realizując projekt unijny. Z kolei 53,8\% przedsiębiorstw deklarowało, że ich zamiary inwestycyjne zostałyby zrealizowane w późniejszym terminie i w zakresie przewidzianym we wniosku przy odmowie unijnego wsparcia, oraz ten sam odsetek firm odłożyłby inwestowanie na późniejszy termin i ograniczyłoby jego zakres również wspomagało się kredytem. Tylko 
$15,3 \%$ średnich jednostek rezygnujących $\mathrm{z}$ inwestycji, gdyby nie otrzymało dofinansowania, korzystało z kredytu bankowego. Wśród tych, które wykonałyby ją w terminie przewidzianym we dokumentacji aplikacyjnej, ale w mniejszym zakresie, 28,6\% sięgnęło po leasing, korzystając z dotacji (rys. 3).

Rys. 3. Stopień realizacji inwestycji małych i średnich firm w sytuacji nieotrzymania refundacji z funduszy strukturalnych w latach 2004-2008 a źródła ich finansowania

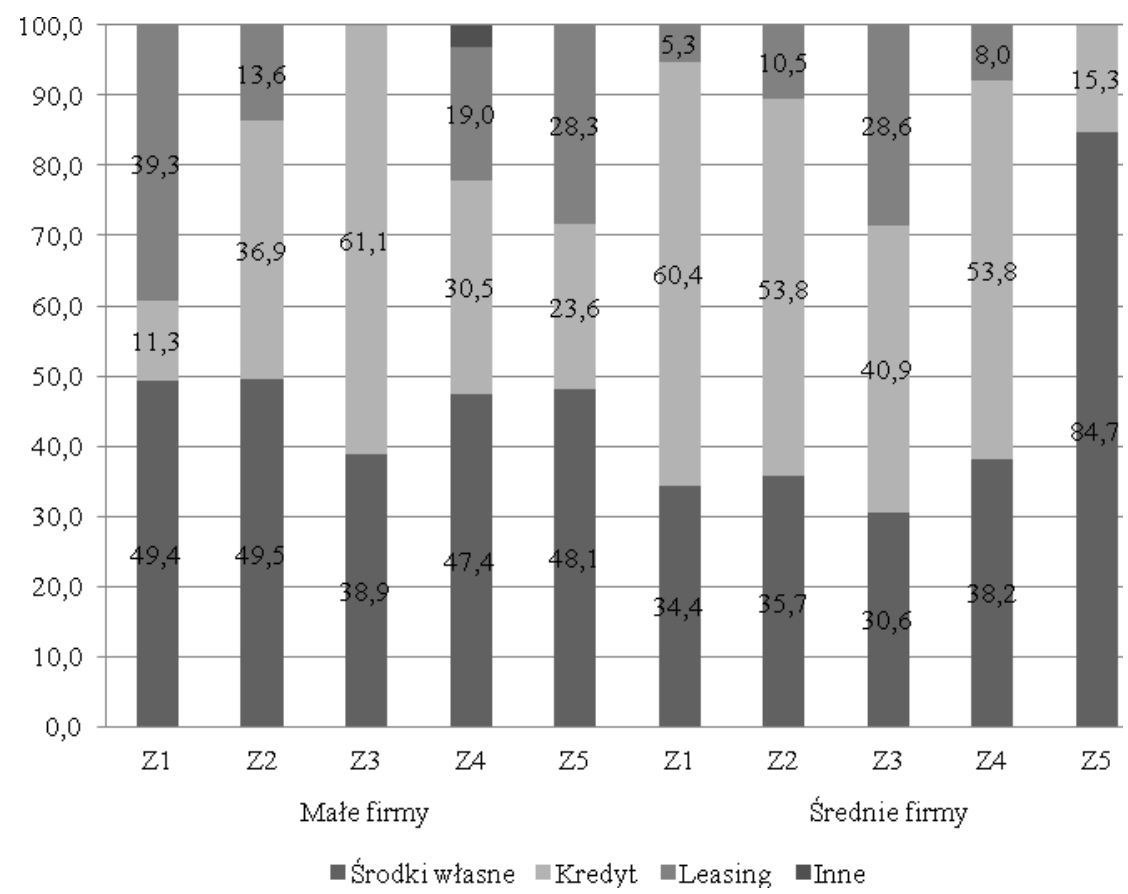

Źródło: opracowanie własne na podstawie informacji zawartych w kwestionariuszach ankietowych Wplyw funduszy strukturalnych na rozwój matych $i$ średnich przedsiębiorstw $w$ województwie wielkopolskim

\section{ZAKOŃCZENIE}

Wyniki zaprezentowanego w artykule badania wskazują, że bez względu na przedmiot inwestycji współfinansowanej z funduszy europejskich najczęściej wybieranym źródłem finansowania małych jednostek są środki własne. Średnie podmioty natomiast chętniej sięgają po zewnętrzne kapitały, głównie finansujące ich inwestycje w wartości niematerialne i prawne. Świadczyć to może nie tylko o silniejszej, niż mniejszych jednostek, sytuacji finansowej podmiotów o średniej skali wytwarzania, ale również o większej orientacji na inwestycje budujące trwalszą przewagę konkurencyjną, czyli wartości niematerialne i prawne ${ }^{9}$.

\footnotetext{
${ }^{9}$ Ł. Skowron, Istota i pomiar niematerialnych zasobów przedsiębiorstwa, Humanities and Social
} Sciences, Vol. XVIII, 2/2013, s. 151-152. 
Środki własne służyły małym podmiotom przede wszystkim do finansowania inwestycji refundowanych ze środków UE i związanych ze zwiększeniem konkurencyjności na rynku krajowym, natomiast kredyt był głównym źródłem finansującym inwestycje służące powiększeniu bazy kapitałowej. Z kolei leasingiem wspierały się najmniejsze podmioty w celu wzmocnienia swojej pozycji na arenie międzynarodowej.

Średnie przedsiębiorstwa najczęściej pokrywały ze środków własnych inwestycje zwiększające ich bazę kapitałową. Kredyt bankowy natomiast służył finansowaniu poprawy konkurencyjności zarówno na rynku krajowym, jak i zagranicznym, poprawy jakości oferowanych dóbr/usług, a także rozwojowi strategii eksportowej.

Małe podmioty przeznaczały własne zasoby finansowe przede wszystkim na inwestycje, które w razie braku dotacji realizowałyby $\mathrm{w}$ terminie $\mathrm{i}$ zakresie przewidzianym we wniosku lub w późniejszym czasie. Wydaje się zatem, że najmniejsze przedsiębiorstwa decydowałyby się na inwestycje najbardziej konieczne dla rozwoju firmy, których realizacja dokonałaby się nawet bez wsparcia unijnego. Z kolei kredyt bankowy był niezbędny małym firmom na finansowanie refundowanych inwestycji, które bez refundacji $\mathrm{z}$ funduszy UE zostałyby wprawdzie zrealizowane $\mathrm{w}$ terminie przewidzianym we wniosku, ale w ograniczonym zakresie.

Znakomita większość średnich przedsiębiorstw ze środków własnych finansowała inwestycje, które przy braku refundacji z funduszy unijnych nie zostałyby zrealizowane w ogóle. Pomoc europejska zatem stanowiła bardzo ważny czynnik proinwestycyjny, determinujący angażowanie własnych zasobów przez podmioty o średniej skali wytwarzania. Nie dziwi zatem wynik badania wskazujący na największy odsetek średnich firm finansujących kredytem bankowym te inwestycje, które bez względu na przyznanie dotacji z funduszy europejskich byłyby finansowane w takim samym czasie i zakresie.

\section{LITERATURA:}

[1] Czternasty W., Mikołajczak P., Rozwój malych i średnich przedsiębiorstw w Polsce a źródla ich finansowania. Wspótczesne dylematy, [w:] Nowe trendy w metodologii nauk ekonomicznych, t. I: Problemy ogólne metodologii nauk ekonomicznych, red. A. Grzelak, K. Pająk, Wydawnictwo UEP, Poznań 2010.

[2] Ernst \& Young, Pomoc Unii Europejskiej dla przedsiębiorców, C.H. BECK, Warszawa 2004

[3] Górka K., Zjawisko luki kapitałowej w finansowaniu mikro-, małych i średnich przedsiębiorstw w Polsce w latach 2007-2011, „Ekonomia, Economics” 4(21), Wydawnictwo Uniwersytetu we Wrocławiu, Wrocław 2012

[4] Ministerstwo Infrastruktury i Rozwoju, http://www.funduszeeuropejskie.gov.pl (dostęp: 28.12.2013).

[5] Mikołajczak P., Zródła finansowania inwestycji matych $i$ średnich przedsiębiorstw refundowanych ze środków strukturalnych Unii Europejskie, [w:] Ryzyko w działalności gospodarczej. Finansowanie matych $i$ średnich przedsiębiorstw w okresie zagrożenia ryzykiem, red. A. Janc, K. Waliszewski, Wydawnictwo UEP, Poznań 2012.

[6] Proczek M., Wsparcie finansowe dla sektora MSP $w$ Polsce z funduszy strukturalnych $w$ latach 2004-2006, [w:] Finansowanie MSP w Polsce ze 
środków finansowych UE jako czynnik wpływająy na konkurencyjność przedsiębiorstw, red. E. Latoszek, Wydawnictwo SGH, Warszawa 2008.

[7] Skowron Ł., Istota $i$ pomiar niematerialnych zasobów przedsiębiorstwa, „Humanities and Social Sciences” XVIII/2 (2013).

[8] Mielcarz P., Paszczyk P., Analiza projektów inwestycyjnych w procesie tworzenia wartości przedsiębiorstwa, Wydawnictwo Naukowe PWN, Warszawa 2013.

\section{THE STRUCTURE OF INVESTMENT FINANCING OF SMALL AND MEDIUM- SIZED ENTERPRISES REFUNDED FROM EUROPEAN FUNDS IN WIELKOPOLSKA}

European Union funds have a positive impact on the dynamics of gross domestic product. European funds increase the competitiveness and innovativeness of the Polish economy, support the development of enterprises, especially entities belonging to the sector of small and medium-sized enterprises. The latter don't have enough capital and foreign sources of funding are very difficult to obtain for them among other things due to the lack of lending capacity and sufficient collaterals. Businesses established in Poland since May 1, 2004 can apply for financial support from many sources. European Union funds in the form of nonrepayable grants are in fact available for Polish companies mainly in the form of community programs and the structural funds. The most popular were programs that Polish companies could get grants for investments in the form of direct support by way of reimbursement of the cost of investment and concessional loans. In the article the structure finance investment projects by small and medium-sized enterprises, which received a grant from the European funds are researched. An attempt was made to identify the object and purposes of the investments made by small businesses on the background of financial funds used by SME. Also examined the scope of the investment of small and medium-sized entities in the face of refusal of reimbursement from the structural funds and in the confrontation with different kind of financial sources. Presented in this article the results of research concern the results of direct assistance to SMEs in the form of refunds from the structural funds in the programming 2004-2006 and accounted for in the next two years. Empirical analysis based on the results of a survey covering 110 companies belonging to the sector of SMEs operating in the Wielkopolska Region, which received funding from the Sectoral Operational Programme Improvement of the Competitiveness of Enterprises. The survey was conducted among 52 small firms and 58 medium-sized companies.

Keywords: firm, investment, credit, structural funds, competitiveness, innovation.

DOI:10.7862/rz.2014.hss.44

Przesłano do redakcji: styczeń 2014

Przyjęto do druku: październik 2014 